\title{
PENYULUHAN DAN BIMBINGAN MENGATASI MODAL USAHA DALAM UPAYA MENINGKATKAN PENDAPATAN PEDAGANG DI KELURAHAN KALISARI, KECAMATAN PASAR REBO JAKARTA TIMUR
}

\author{
Uuh Sukaesih', Miswan² \\ Fakultas Ekonomi dan Bisnis, Universitas Sahid \\ Jl. Prof. Dr. Soepomo No. 84, Tebet, Jakarta Selatan \\ Email Korespondensi: sukaesihuuh@yahoo.co.id
}

\begin{abstract}
ABSTRAK
Tujuan dari penyuluhan dan bimbingan yaitu: 1) Para pedagang mengetahui ada lembaga keuangan yang menyediakan kredit modal usaha (Kredit Usaha Rakyat/KUR), 2) Pedagang yang mengalami kesulitan modal dapat mengajukan kredit Usaha Rakyat, 3) Pedagang bisa mengembangkan usaha sehingga pendapatan dan keuntungan meningkat. Metode yang dilakukan dengan memberikan penyuluhan mengenai Kredit Usaha Rakyat dengan persyaratan mudah dan bunga rendah. Selanjutnya bagi pedagang berminat dilakukan bimbingan dan pendampingan cara mengajukan kredit, juga pendampingan dan konsultasi agar mereka mampu mengembalikan kredit sesuai waktu yang telah ditetapkan. Tim abdimas dari bulan Oktober 2018 sampai Desember 2018 telah melakukan penyuluhan kepada sebanyak 30 orang pedagang yang ada di RW 03 Kelurahan Kalisari Kecamatan Pasar Rebo Jakarta Timur. Dari 30 orang tersebut yang berminat mengajukan kredit sebanyak 5 orang, dan mendapatkan kredit Usaha Rakyat (KUR), juga telah membayar angsuran kredit dengan lancar setiap bulan. Selain itu juga pendapatan rata-rata meningkat 20 persen, dan keuntungan meningkat rata-rata 15 persen.
\end{abstract}

Kata Kunci : Penyuluhan, Bimbingan, Modal Usaha, Pendapatan, Pedagang

\begin{abstract}
The objectives of counseling and guidance are: 1) Traders know that there are financial institutions that provide business capital loans $(K U R), 2)$ Traders who experience capital difficulties can apply for People's Business loans, 3) Traders can develop businesses so that income and profit increases. The method is carried out by providing counseling on People's Business Credit with easy requirements and low interest. Furthermore, traders are interested in providing guidance and assistance on how to apply for credit, as well as assistance and consultation so that they are able to return credit within the stipulated time. The abdimas team from October 2018 to December 2018 had conducted counseling to as many as 30 traders in RW 03 Kalisari Village, Pasar Rebo District, East Jakarta. Of the 30 people who are interested in applying for credit as many as 5 people, and get a People's Business credit (KUR), also have to pay the loan installments smoothly every month. In addition, the average income increased by 20 percent, and profits increased by an average of 15 percent.
\end{abstract}

Keywords: Counseling, Guidance, Business Capital, Income, Traders 


\section{PENDAHULUAN}

Propinsi DKI Jakarta merupakan pusat pemerintahan dan perekonomian yang mendorong banyak penduduk dari luar Jakarta datang berbondong-bondong mencari rezeki di ibu kota Negara Indonesia ini. Para pendatang tersebut banyak yang tidak dibekali dengan keahlian atau keterampilan khusus, sehingga biasanya kehadiran mereka menimbulkan beberapa dampak sosial yang sangat sulit tertangani, seperti masalah pengangguran, kemiskinan, dan kriminalitas. Jumlah penduduk di Kelurahan Kalisari, Kecamatan Pasar Rebo Jakarta Timur (laporan Juni 2019) sebanyak 50323 jiwa, yang terdiri dari 25337 jiwa laki-laki (50,35 persen) dan 24986 perempuan $(49,65$ persen). Berdasarkan pekerjaan yang paling banyak sebagai karyawan swasta/Pemerintah/ABRI yaitu 17518 jiwa atau 34,81 persen, jumlah pedagang atau yang berwirausaha sebanyak 5347 jiwa atau 10,62 persen, sedangkan jumlah pengangguran sebanyak 4821 jiwa atau 9,58 persen. Jumlah pengangguran dapat menyebabkan kerawanan sosial, jika mereka tidak mampu untuk menciptakan kerja sendiri atau berwirausaha. Upaya yang bisa dilakukan oleh pengangguran atau yang belum mendapat pekerjaan yaitu dengan berwirausaha atau menjadi pedagang karena untuk bekerja sebagai Karyawan Swasta/Pemerintah/ABRI yang sebenarnya banyak diminati kesempatannya relative kecil.

Menurut hasil observasi lapangan para pedagang atau pengusaha tersebut lebih dari 90 persen tidak mengetahui bahwa ada Kredit Usaha Rakyat (KUR) disalurkan oleh beberapa bank dengan suku bunga sangat rendah yaitu sebesar 3,8 persen per tahun karena mendapat subsidi dari pemerintah yang bertujuan untuk membantu permodalan para pengusaha kecil yang ada di Indonesia. Walaupun keberadaan KUR gencar diiklankan di Televisi. Berdasarkan hasil observasi juga ditemukan beberapa pengusaha kecil yang ada di kelurahan Kalisari sering mengalami kesulitan dalam hal permodalan. Langkah yang dilakukan yaitu meminjam dari saudara, bahkan ada yang meminjam dari Rentenir, ada juga yang meminjam dari Bank keliling karena orang yang meminjamkan uang datang berkeliling kampung untuk menawarkan jasa peminjaman uang dan dibayar secara rutin setiap hari. Suku bunga yang harus dibayar jika meminjam dari rentenir atau bank keliling sekitar 20 persen per bulan.

Tujuan dari penyuluhan dan bimbingan yaitu: 1) Para pedagang mengetahui ada lembaga keuangan yang menyediakan kredit modal usaha (Kredit Usaha Rakyat/KUR) dengan persyaratan mudah dengan bunga kecil sebesar 3,8 persen per tahun, 2) Pedagang yang mengalami kesulitan modal dapat mengajukan kredit Usaha Rakyat, 3) Pedagang bisa mengembangkan usaha sehingga pendapatan dan keuntungan meningkat.

\section{METODE PELAKSANAAN}

Metode yang dilakukan untuk "Mengatasi Modal Usaha dalam Upaya untuk meningkatkan pendapatan pedagang di Kelurahan Kalisari Kecamatan Pasar Rebo Jakarta Timur" dengan langkah-langkah sebagai berikut:

1. Memberikan penyuluhan atau informasi kepada para pedagang atau pengusaha kecil bahwa ada lembaga keuangan yaitu Bank Rakyat Indonesia (Kantor Unit BRI) yang menyediakan kredit modal usaha dengan nama Kredit Usaha Rakyat (KUR) dengan persyaratan mudah dan tingkat bunga kecil yaitu 3,8 persen per tahun 
2. Memberikan penyuluhan atau informasi kepada pedagang atau pengusaha kecil yang berminat tentang cara dan prosedur untuk mendapatkan kredit modal usaha dengan nama Kredit Usaha Rakyat (KUR)

3. Melakukan pendampingan (konsultasi), dan pelatihan bagi pedagang atau pengusaha kecil yang akan mengajukan kredit modal usaha dengan nama Kredit Usaha Rakyat (KUR)

4. Mengantar untuk datang ke Bank Rakyat Indonesia terdekat, bagi pedagang atau pengusaha kecil yang tidak berani datang sendiri untuk mengajukan kredit tersebut

Untuk melaksanakan kegiatan tersebut dibagi dalam 3 tahapan kegiatan mulai dari persiapan, konfirmasi sampai pada tahap pelaksanaan kegiatan. Uraian masing-masing kegiatan yaitu sebagai berikut:

1. Tahap Persiapan dan Perencanaan

Tahap persiapan dan perencanaan dilakukan untuk mengadakan berbagai persiapan yang diperlukan untuk pelaksanaan kegiatan di lapangan. Tahap Persiapan dan perencanaan dilakukan untuk menentukan: Materi penyuluhan, tempat penyuluhan, dan waktu atau tanggal dan jam penyuluhan akan dilakukan.

2. Tahap konfirmasi Kegiatan.

Pada tahap ini dilakukan komunikasi secara langsung dengan Bapak ketua Rt yang ada Kelurahan Kalisari Kecamatan Pasar Rebo Jakarta Timur untuk memberitahukan bahwa akan dilaksanakan kegiatan "Penyuluhan Dan Bimbingan Mengatasi Modal Usaha Dalam Upaya Meningkatkan Pendapatan Pedagang". Dari hasil konfirmsi tersebut Bapak Ketua RT menyarankan kegiatan dilakukan kepada para pedagang yang ada di wilayah tersebut. Karena para pedagang tersebut mempunyai kesibukan yang berbeda-beda, maka Bapak Ketua RT menyarankan seandainya mereka tidak bisa dikumpulkan pada waktu tertentu dan di tempat tertentu, maka sebaiknya didatangi langsung ke tempat usaha masingmasing. Hal ini dilakukan agar tidak ada lagi penghalang-penghalang atau hambatan yang berhubungan dengan persiapan dan pelaksanaan. Pada tahap ini diharapkan juga sudah ada koordinasi yang baik antara tim dengan mitra.

3. Tahap Pelaksanaan Kegiatan.

Pelaksanaan kegiatan penyuluhan akan dilaksananakan di minggu pertama setiap Hari Sabtu dan Minggu pada bulan September 2018 sampai bulan April 2019. Kegiatan akan dilaksanakan di Perumahan warga Kelurahan Kalisari Kecamatan Pasar Rebo Jakarta Timur.

\section{HASIL DAN PEMBAHASAN}

\section{Pelaksanaan Penyuluhan Mengenai Kredit Usaha Rakyat}

Pengerian penyuluhan menurut Undang-undang Nomor 16/2006 tentang Sistem Penyuluhan Pertanian, Perikanan dan Kehutanan yaitu "proses pembelajaran bagi pelaku utama serta pelaku usaha agar mereka mau dan mampu menolong dan mengorganisasikan dirinya dalam mengakses informasi pasar, teknologi, permodalan, dan sumberdaya lainnya, sebagai upaya untuk meningkatkan produktivitas, efisiensi usaha, pendapatan, dan kesejahteraannya, serta meningkatkan kesadaran dalam pelestarian fungsi lingkungan hidup. Sebagai sebuah suatu tindakan praktis, penyuluhan merupakan upaya-upaya yang dilakukan untuk mendorong terjadinya 
perubahan perilaku pada individu, kelompok, komunitas, ataupun masyarakat agar mereka tahu, mau, dan mampu menyelesaikan permasalahan yang dihadapi. Tujuan penyuluhan tidak lain adalah hidup dan kehidupan manusia yang berkualitas dan bermartabat (Amanah, 2007).

Penyuluhan yang dilakukan yaitu dengan memberi informasi bahwa apabila pemilik usaha mengalami kesulitan modal dalam menjalankan usaha maka ada lembaga keuangan yaitu bank yang bersedia membantu mengatasi modal usaha dengan memberi pinjaman kredit. Menurut Kamus Besar Bahasa Indonesia modal usaha artinya uang yang dipakai sebagai pokok (induk) untuk berdagang, melepas uang, dan sebagainya; harta benda (uang, barang, dan sebagainya) yang dapat dipergunakan untuk menghasilkan sesuatu yang menambah kekayaan". Modal dalam pengertian ini dapat diinterpretasikan sebagai sejumlah uang yang digunakan dalam menjalankan kegiatankegiatan bisnis. Modal usaha bisa bersumber dari modal sendiri, pinjaman dari keluarga, dan pinjaman dari lembaga keuangan baik dari bank atau non bank. Modal yang berasal dari pinjaman biasa disebut dengan kredit.

Pengertian kredit Menurut Undang-undang Perbankan Nomor 10 Tahun 1998: "kredit adalah penyediaan uang atau tagihan-tagihan yang dapat disamakan dengan itu, berdasarkan persetujuan atau kesepakatan pinjam meminjam antara bank dengan pihak lain dalam hal mana pihak peminjam berkewajiban melunasi utangnya setelah jangka waktu tertentu dengan jumlah bunga yang telah ditetapkan". Menurut Kasmir (2015:85), Kredit diartikan memperoleh barang dengan membayar dengan cicilan atau angsuran dikemudian hari atau memperoleh pinjaman uang yang pembayarannya dilakukan dikemudian hari dengan cicilan atau angsuran sesuai dengan perjanjian. Menurut Kasmir (2015:88) adapun tujuan utama pemberian suatu kredit adalah sebagai berikut:

1. Mencari Keuntungan. Yaitu bertujuan untuk memperoleh hasil dari pemberian kredit tersebut. Hasil tersebut terutama dalam bentuk bunga yang diterima oleh bank sebagai balas jasa dan biaya administrasi kredit yang dibebankan kepada nasabah. Keuntungan ini penting untuk kelangsungan hidup bank. Jika bank yang terusmenerus menderita kerugian, maka besar kemungkinan bank tersebut akan di likuiditasi (dibubarkan).

2. Membantu Usaha Nasabah. Yaitu membatu usaha nasabah yang memerlukan dana baik dana investasi maupun dana modal kerja. Dengan dana tersebut maka pihak debitur akan dapat mengembangkan dan memperluaskan usahanya.

3. Membantu Pemerintah. Bagi pemerintah semakin banyak kredit yang disalurkan oleh perbankan, maka semakin baik mengingat semakin banyak kredit berarti adanya peningkatan pembangunan berbagai sektor.

Sebelum melakukan penyuluhan tim pengabdian masyarakat datang ke Bank Rakyat Indonesia Unit Kalisari (Gambar 1 dan Gambar 2) untuk mendapatkan informasi mengenai program Kredit Usaha Rakyat (KUR). Menurut informasi dari BRI, pihak BRI sebagai penyalur KUR membenarkan bahwa ada kredit yang bertujuan untuk membantu permodalan untuk pedagang atau yang memiliki usaha kecil, dengan ketentuan yaitu:

1. Suku bunga ringan yaitu $3,8 \%$ efektif per tahun

2. Syarat mudah (usaha minimal 6 bulan)

3. Bebas biaya administrasi dan provisi

4. Plafond sampai Rp 25 juta 
Persyaratan mengajukan KUR yaitu:

1. Foto Copy KTP suami istri

2. Pas Foto suami dan istri ukuran $4 \times 6$

3. Foto Copy Kartu Keluarga

4. Foto Copy Surat Nikah

5. Surat Keterangan Usaha (dari Kelurahan)

6. Tidak sedang menikmati kredit modal kerja dan investasi dari Bank lain

Menurut Komite Kebijakan KUR (2010) dalam Widiastuti (2017) Kredit Usaha Rakyat (KUR) adalah kredit/pembiayaan kepada Usaha MIkro Kecil Menengah (UMKM) dalam bentuk pemberian modal kerja dan investasi yang didukung fasilitas penjaminan untuk usaha produktif dan layak (feasible) namun mempunyai keterbatasan dalam pemenuhan persyaratan yang ditetapkan perbankan (non bankable).

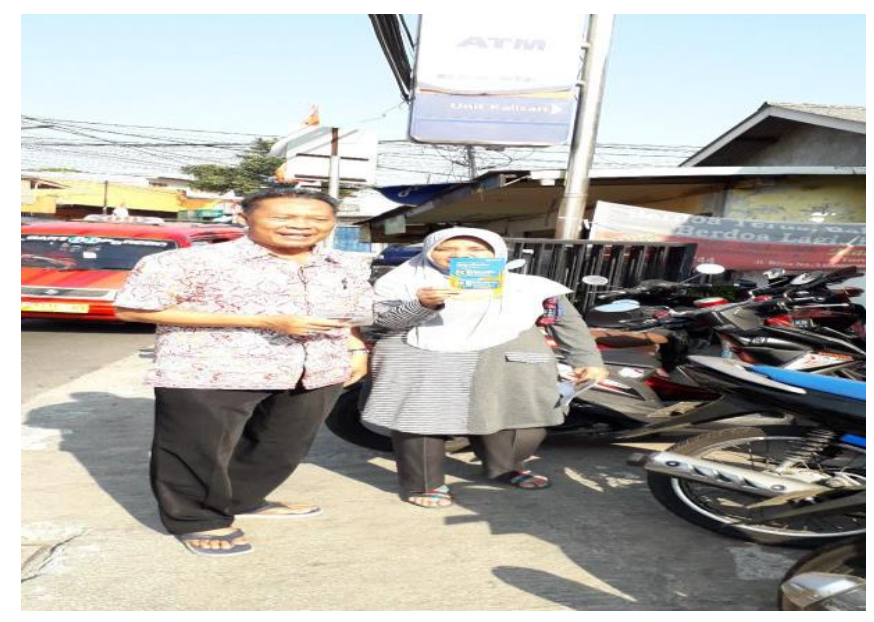

Gambar 1. Tim Mendatangi Bank yang Menyalurkan KUR

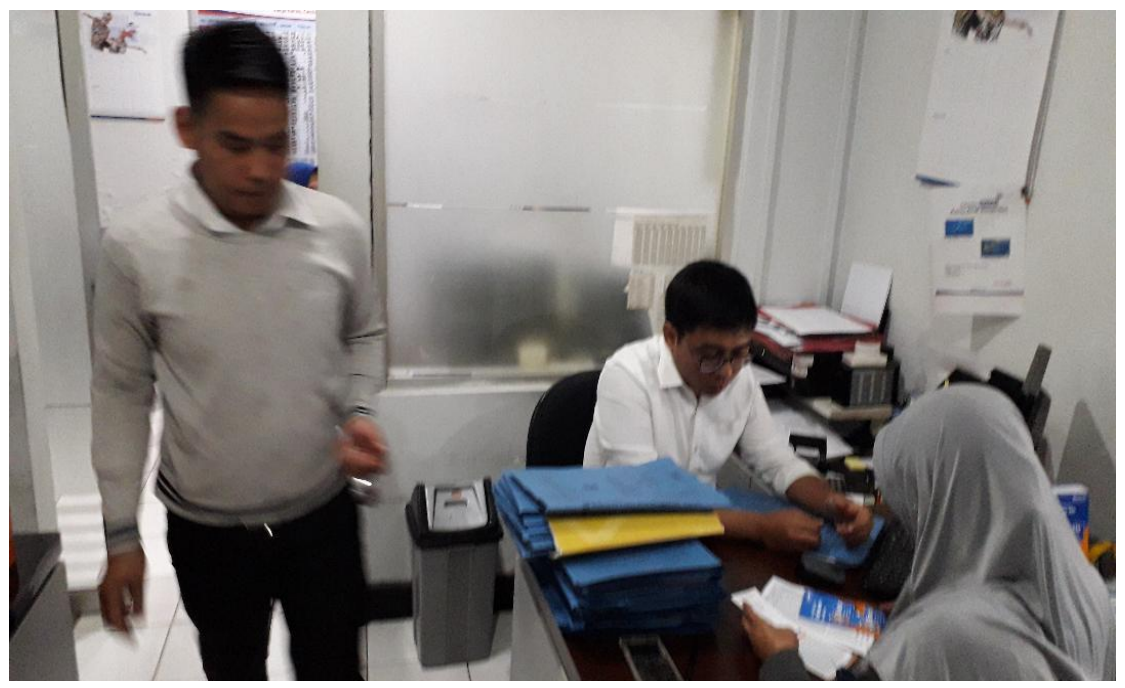

Gambar 2. Tim Pengabdian Mencari Informasi Mengenai KUR 
Penyuluhan atau pemberian informasi mengenai adanya KUR yang bertujuan untuk membantu pedagang atau yang punya usaha yang membutuhkan modal usaha dilakukan di rumah warga RT10 RW 03 Kelurahan Kalisari, Kecamatan Pasar Rebo, Jakarta Timur pada hari Minggu tanggal 7 Oktober 2018 dengan dihadiri 10 0rang, yang merupakan warga RT 05, 07, dan 10 RW 03 Kelurahan Kalisari, Kecamatan Pasar Rebo, Jakarta Timur. Pedagang dan warga yang punya usaha sedikit yang hadir karena mereka mempunyai kesibukan untuk mempersiapkan dagangan atau usahanya, sehingga sesuai dengan saran dari Bapak RT akhirnya penyuluhan dan pemberian informasi dilakukan dengan cara datang ke rumah atau ke tempat usaha masing-masing. Jumlah pedagang yang diberi penyuluhan mengenai adanya Kredit Usaha yang disalurkan oleh Bank Rakyat Indonesia yang bertujuan untuk membantu mengatasi modal usaha sebanyak 30 orang. Dari jumlah tersebut yang berminat mengajukan kredit sebanyak 5 orang. Sedikitnya yang berminat mengajukan kredit dari Bank dikarenakan para pedagang menganggap untuk meminjam uang dari bank harus ada jaminan, juga kalo meminjam uang dari bank merasa khawatir seandainya tidak lancar membayar cicilan karena pendapatan yang diperoleh dari usahanya tidak menentu jaminan yang telah diserahkan ke bank akan menjadi barang sitaan bank.

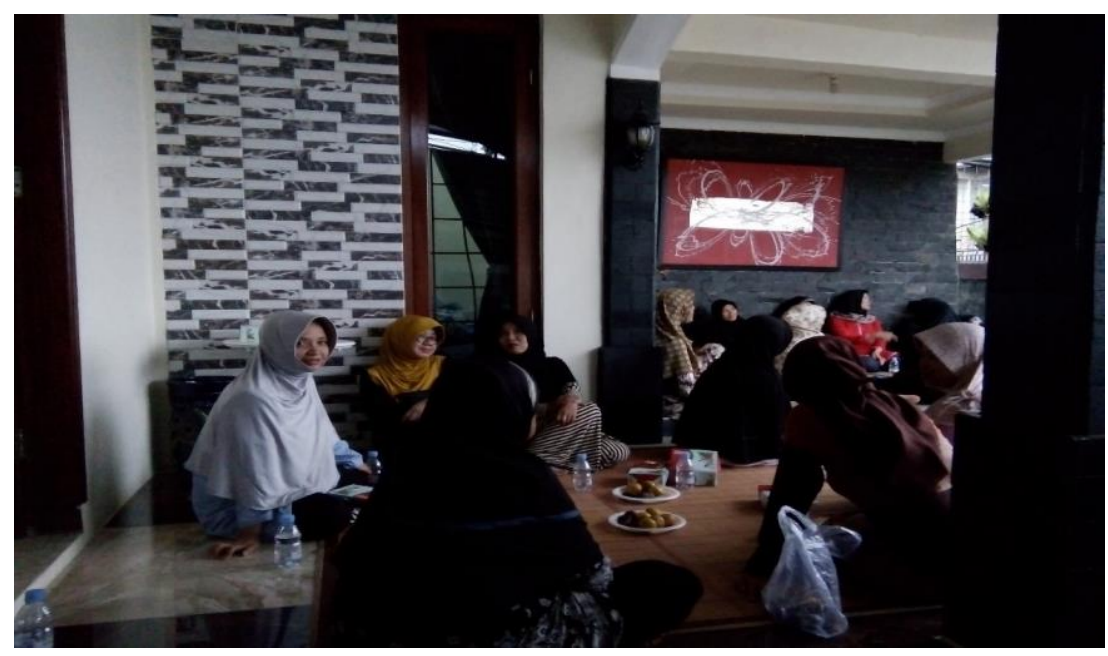

Gambar 3. Peserta yang Hadir Saat Penyuluhan

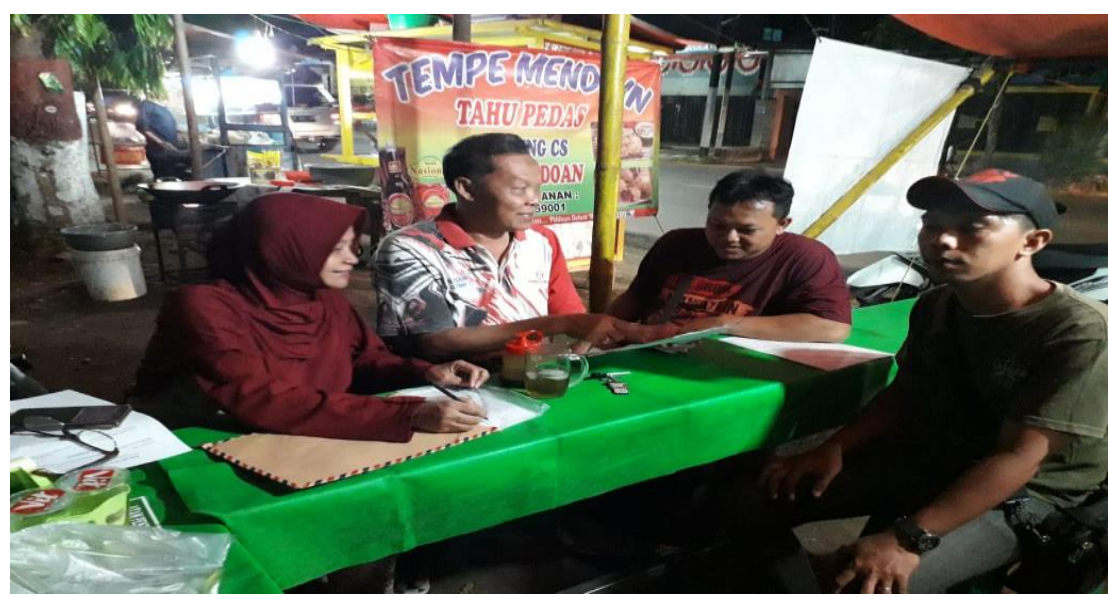

Gambar 4. Tim Abdimas Memberi Penyuluhan dengan Mendatangi Mitra 


\section{Bimbingan dan Pendampingan untuk Mendapatkan Kredit Usaha Rakyat (KUR)}

Bimbingan dan pendampingan terhadap mitra yaitu pedagang atau yang mempunyai usaha dilakukan untuk yang memerlukan tambahan modal atau bermaksud akan mengajukan pinjaman kredit namun mereka merasa kurang jelas mengenai persyaratan yang harus dipersiapkan dan merasa hawatir meminjam uang dari bank kalau tidak lancar mencicil akan bermasalah, diantaranya ada kehawatiran dilakukan penyegelan. Untuk mengatasi hal tersebut dilakukan arahan dan bimbingan. Bimbingan dan pendampingan untuk mengajukan KUR dilakukan kepada pedagang yang berminat mengajukan kredit. Bimbingan dilakukan mulai dari:

1. Mempersiapkan persyaratan untuk mengajukan kredit,

2. Mengantar ke Bank Rakyat Indonesia untuk mengajukan kredit, karena tidak semua yang akan mengajukan kredit berani datang sendiri ke Bank. Oleh BRI diberi formulir isian pengajuan kredit. Dari 5 orang yang mengajukan kredit hanya 1 orang yang berani datang sendiri ke Bank untuk mengajukan pinjaman kredit, sedangkan 4 orang diantar untuk datang ke Bank.

3. Membantu mengisi formulir pengajuan kredit (Gambar 5).

4. Mengantar lagi ke Bank Rakyat Indonesia untuk menyerahkan formulir pengajuan kredit (Gambar 6).

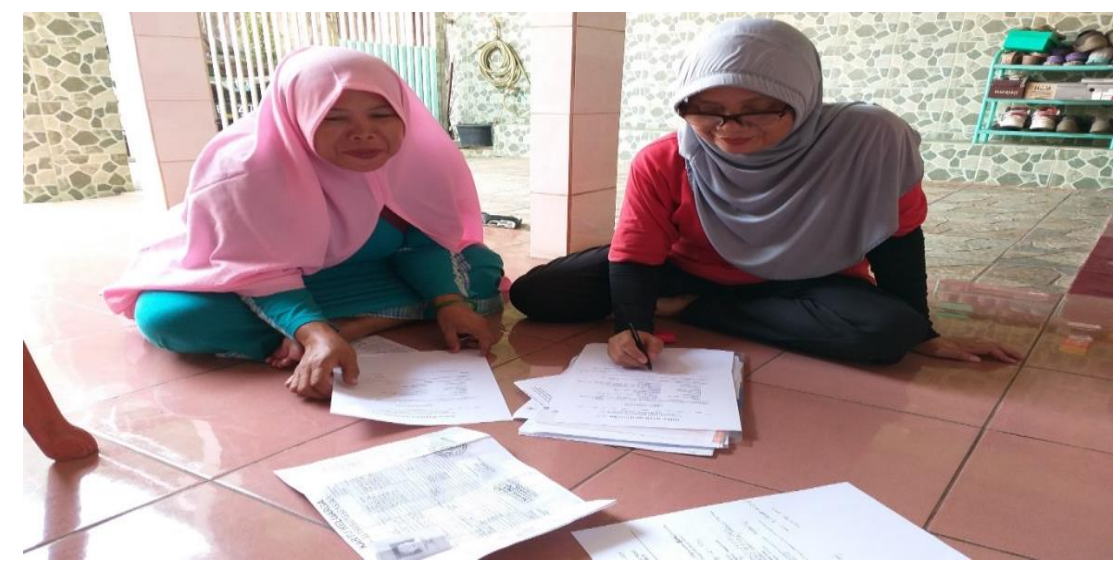

Gambar 5. Tim Membantu Mengisi Formulir Pengajuan Kredit

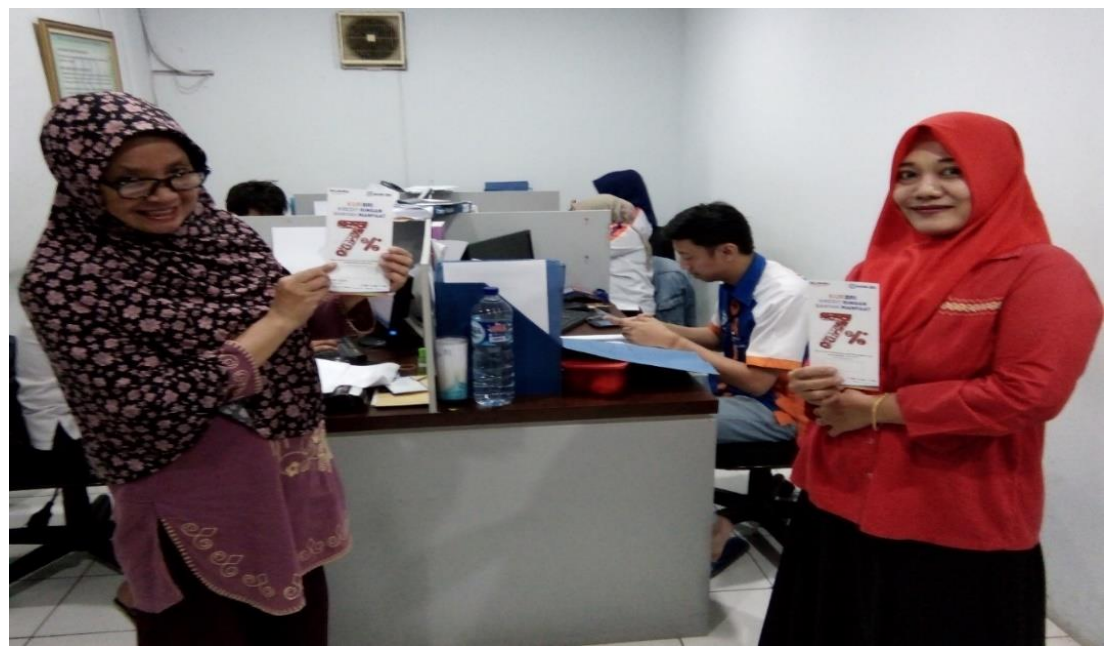

Gambar 6. Tim Pengabdian Masyarakat Mengantar Ke BRI 


\section{Bimbingan dan Pendampingan Setelah Mendapatkan Kredit Usaha Rakyat (KUR)}

Bimbingan dan pendampingan kepada pedagang atau pengusaha yang telah mendapatkan kredit tetap dilakukan agar kredit yang diperoleh digunakan sebaikbaiknya sehingga bisa mencicil kredit sesuai dengan waktu yang telah ditetapkan. Berdasarkan informasi dari mitra yaitu yang mengajukan kredit, mereka setiap bulan lancar mengembalikan kreditnya. Bimbingan dan pendampingan dilakukan dengan secara memberi arahan agar usahanya lebih baik, sehingga pendapatan atau keuntungan yang diperoleh meningkat. Bimbingan dan pendampingan terus dilakukan secara rutin sampai bulan Agustus 2019.

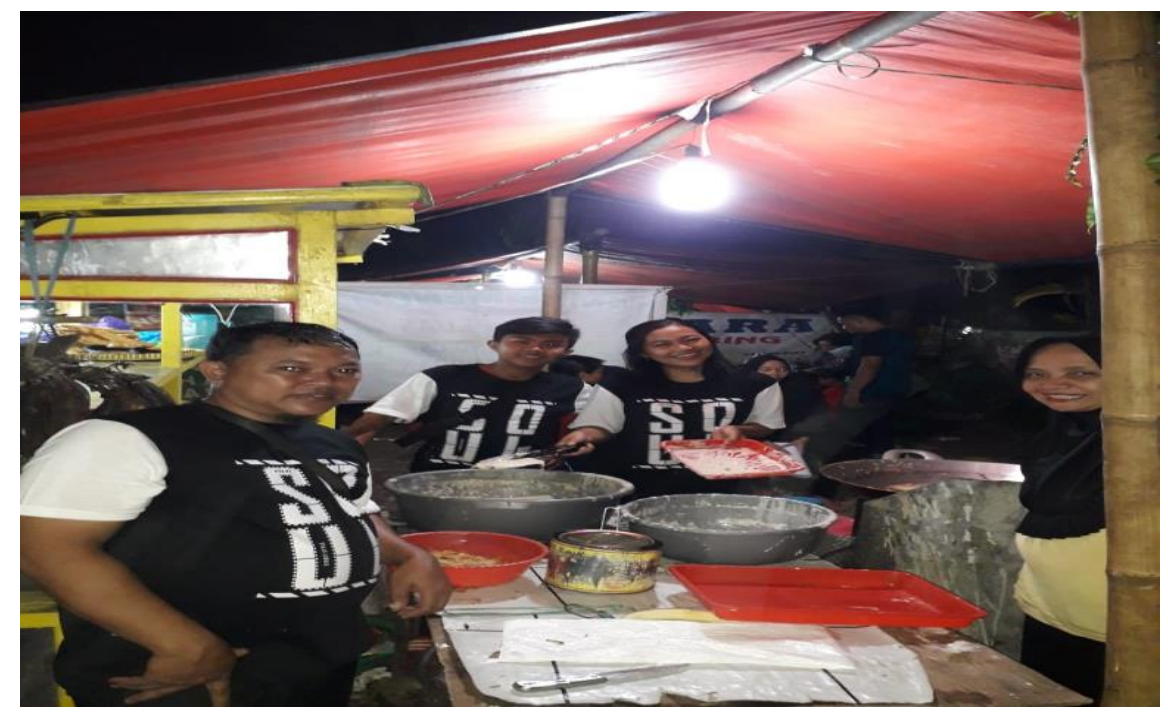

Gambar 7. Tim Abdimas Memberi Arahan Setelah Memperoleh KUR

\section{Manfaat Kredit Usaha Rakyat (KUR)}

Menurut informasi dari pedagang yang mengajukan kredit (KUR), dana pinjaman yang diperoleh sebagian digunakan untuk mengontrak tempat usaha dan sebagian untuk menambah modal usaha, sehingga variasi dan jumlah barang yang diproduksi bertambah.

Manfaat yang dirasakan mitra setelah sekitar 10 bulan memperoleh pinjaman kredit yaitu:

1. Program Kredit Usaha Rakyat (KUR) dapat menambah modal usaha sehingga jumlah dan variasi (jenis barang) yang dijual bertambah dan nilai penjualan barang atau pendapatan naik rata-rata 20 persen, yaitu dari rata-rata nilai penjualan $\mathrm{Rp}$ 800.000 menjadi Rp 960.000 per hari.

2. Program Kredit Usaha Rakyat (KUR) dapat meningkatkan keuntungan yang diperoleh setiap harinya, sehinga keuntungan per bulan juga meningkat rata-rata 15 persen, yaitu dari rata-rata Rp 300.000 menjadi Rp 450.000 per hari.

3. Dengan meningkatnya keuntungan maka mitra dapat menyisihkan keuntungan tersebut untuk menabung. 


\section{KESIMPULAN}

Kesimpulan dari kegiatan ini yaitu :

1. Para pedagang yang ada di Kelurahan Kalisari Kecamatan Pasar Rebo Jakarta Timur mengetahui bahwa ada lembaga keuangan yaitu bank yang menyediakan Kredit Usaha Rakyat (KUR) dengan persyaratan mudah dan tingkat bunga 3,8 \% per tahun.

2. Dari 30 pedagang yang diberi penyuluhan ada 5 pedagang yang mengajukan kredit.

3. Dengan adanya pinjaman kredit maka pendapatan dan keuntungan pedagang meningkat.

\section{UCAPAN TERIMA KASIH}

Penulis mengucapkan terima kasih kepada Universitas Sahid Jakarta yang telah memberi dukungan financial terhadap kegiatan pengabdian masyarakat ini.

\section{DAFTAR PUSTAKA}

Amanah, S. (2007). Makna penyuluhan dan transformasi perilaku manusia. Jurnal penyuluhan, 3(1).

Bygrave, W. D. (2011). The entrepreneurial process. In The portable MBA in entrepreneurship.

Kasmir. (2015). Manajemen Perbankan. Edisi Revisi. Jakarta. PT. Raja Grafindo Persada.

Suryana, Y., \& Bayu, K. (2014). Kewirausahaan Pendekatan Karakteristik Wirausahawan Sukses Edisi Kedua. Kencana Prenada Media Group. Jakarta.

Suryana, S. (2014). Kewirausahaan: Kiat dan Proses menuju Sukses. Jakarta: Salemba Empat..

Widiastuti, R., \& Rita, M. R. (2017). Apakah Kredit Usaha Rakyat (KUR) Berdampak pada Kinerja Usaha? (Studi pada UMKM Makanan Ringan Di Kota Salatiga). Jurnal Visi Manajemen, 2(2). 